
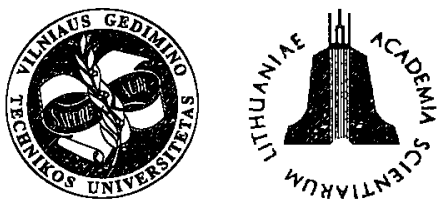

ISSN 1648-4142 TRANSPORT

http:/www.vtu.lt/english/editions

TRANSPORT - 2003, Vol XVIII, No 4, 162-167

\title{
THE INVESTIGATION AND PECULIARITIES OF CALCULATION OF TRANSPORT MACHINE ELEMENTS MADE OF AUSTEMPERED DUCTILE IRON
}

\author{
Mindaugas Leonavičius ${ }^{1}$, Algimantas Krenevičius ${ }^{2}$, Marijonas Šukšta ${ }^{3}$, Jukka Posa ${ }^{4}$ \\ 1, 2,3 Dept strength of materials, Vilnius Gediminas Technical University, \\ Sauletekio al.11,LT-2040 Vilnius, Lithuania.E-mail:minleo@fm.vtu.lt \\ ${ }^{4}$ Metso Drives Oy, Santasalonkatu 5, PO Box 27, FIN-03601 Karkkila, Finland
}

Received 200301 14; accepted 20030114

\begin{abstract}
In this article the statical and cyclical strength investigations of austempered ductile cast iron (ADI) are presented. ADI material becomes more and more popular. Ductile iron is lighter than steel and its mechanical properties are better. ADI has good resistance to fatigue, high tensile strength, toughness and ductility. The fatigue crack initiation generally occurs in the graphite matrix. In the work the kinetic fatigue diagrams, longevity distributions laws and the mathematical model of crack growth ratio are described.

The blanks of material were cut from a tooth of gear. Structure of the material consists of bainite and spherical graphite. The mechanical properties of ADI were obtained with assessment of chemical composition. The determined statical mechanical properties of two different ADI materials are presented. The compact specimen was produced in order to determine a threshold stress intensity factor. According to the investigations the stress intensity factor (threshold) is $\Delta K_{t h}=9,8 \mathrm{MPa} \sqrt{\mathrm{m}}$ for the ADI 6.2.02 and $\Delta K_{t h}=8,6 \mathrm{MPa} \sqrt{\mathrm{m}}$ for the ADI 9.4.02. The carried out investigations are insufficient for the complete evaluation of austempered ductile iron for the production of transport equipment elements.
\end{abstract}

Keywords: fatigue, crack growth, threshold, stress intensity, tooth gear, ductile iron, compact specimen.

\section{Introduction}

Assurance of longer service life and increase of reliability both for machinery used in transport sectors and for various constructions are associated with many factors making their impact on limit states and playing a decisive role in defining the strength of separate members of a structure as well as of the structure, as a whole. Malfunctioning of such objects is usually accompanied by the necessity to put the machinery to a standstill, to evaluate the threat of emergency more realistically and to be ready to face prominent material losses. Malfunctioning, the occurrence that still takes place in a manufacturing process proves that the design, production and maintenance procedures are, unfortunately, imperfect. While determining or specifying the resource of potentially dangerous objects that are either in the design or operation stage, the assurance of appropriate strength to every element thereof by making a multilateral use of material properties is crucial.

Austempered ductile iron becomes more popular in the production of various dimensions transport machines. The development of this material includes chemical composition and structure modeling in the produc- tion process, static mechanical and cyclic features research of made material.

The literary review on the research of austempered ductile iron and the applications of ductile iron for transport machine elements is presented in [1-15].

Ductile iron is $10 \%$ lighter than steel. It is easily cast into complex shapes. When subjected to specially designed austempered heat treatment, it can exhibit remarkable properties. The available grades of ADI and their minimum properties are outlined in ASTM 897-90, ASTM 897M-90 and are shown in Table 1. Fig 1 shows the typical properties of commercial austempered ductile iron.

Ductile cast irons have superior mechanical properties to conventional cast irons due to the nodular shape of the graphite. The matrix of cast irons can vary from ferritic to fully pearlitic, and can be modified by heat treatment such as austempering. Austempered ductile iron (ADI) has an ausferrite matrix of bainite and retained austenite. They have good resistance to fatigue and wear and possess a combination of high tensile strength, toughness and ductility. Typical applications include crankshafts and large gears in transport and lifting applications in which resistance to fatigue failure is required. 
Table 1. Current ASTM A897

\begin{tabular}{|c|c|c|c|c|c|c|c|}
\hline \multicolumn{2}{|c|}{ Tensile Strength } & \multicolumn{2}{|c|}{ Yield Strength } & \multirow{2}{*}{$\begin{array}{c}\text { Percent Elongation } \\
(\%)\end{array}$} & \multicolumn{2}{|c|}{ Charpy (unnotched) } & \multirow[t]{2}{*}{ BHN Hardness Range } \\
\hline (KSI) & $(\mathrm{MPa})$ & (KSI) & $(\mathrm{MPa})$ & & (ft.-b.) & $(\mathrm{J})$ & \\
\hline 125 & 850 & 80 & 550 & 10 & 75 & 100 & $269-321$ \\
\hline 150 & 1050 & 100 & 700 & 7 & 60 & 80 & $302-363$ \\
\hline 175 & 1200 & 125 & 850 & 4 & 45 & 60 & $341-444$ \\
\hline 200 & 1400 & 155 & 1100 & 1 & 25 & 35 & $388-477$ \\
\hline 230 & 1600 & 185 & 1300 & * & $*$ & $*$ & $444-555$ \\
\hline
\end{tabular}

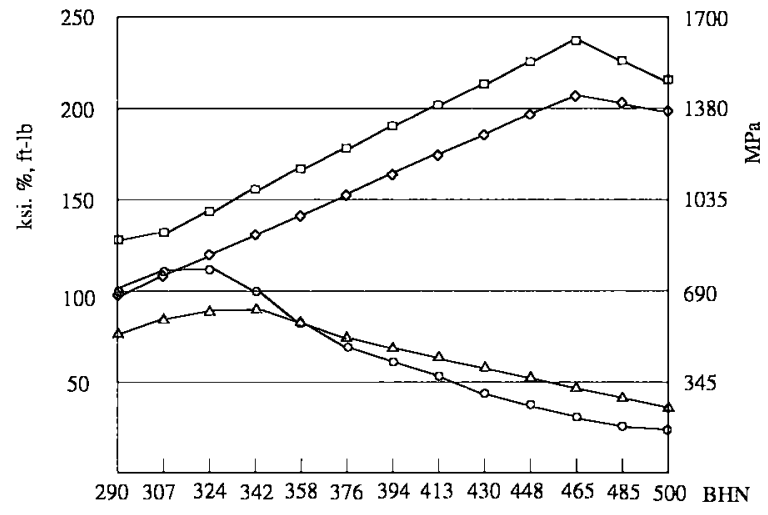

Fig 1. Typical properties of ADI as a function of Brinell hardness BHN: $\square$-Tensile Strength (ksi); $\diamond$ - Yield Strength (ksi); $\mathrm{O}-\%$ Elongation (divided by 10 ); $\triangle$ - Un-notched Charpy Impact (ft-lbs.)

The maximum fatigue resistance in ductile irons occurs at intermediate strength. This coincides with increased ductility due to a maximum of retained austenite obtained in austempered materials.

Fatigue crack initiation in ductile irons generally occurs at the graphite nodule/matrix interface due to the weak interface bond and the low graphite stiffness. However, crack initiation may also occur at other nonmetallic inclusions and micro - shrinkage porosity.

The fatigue limit in austempered ductile cast irons increases with both the retained austenite content and the carbon content of the retained austenite. The mechanism is not known, but it has been suggested that the retained austenite affects crack initiation or propagation through either cyclic strain hardening or martensitic transformation. It has also been found that higher austenisation temperatures decrease the fatigue limit of austempered ductile irons.

The fatigue $\sigma-N$ curve (cyclic stress versus the number of cyclic to failure) is commonly used to access fatigue resistance. In a material which does not have an infinite life fatigue limit, the safe - life fatigue limit or endurance limit is typically the stress for the life of $10^{6}$ or $10^{7}$ cycles. In general, the initiation of fatigue cracks is effectively instantaneous in most materials in high cycle fatigue. The crack nucleus grows very rapidly after initiation and then decelerates due to its interaction with microstructure barriers such as grain boundaries or hard phases such as pearlite. Below the fatigue limit the cracks eventually cease to propagate and are stable. In material with a fatigue endurance limit all initiated cracks may not arrest, although propagation rates may become very slow in the vicinity of microstructure barriers.

This behavior is typical of microstructure short cracks, which have a size of the same order as the spacing of microstructure barriers. Longer cracks can be influenced by the microstructure in the physical short crack regime. The cracks propagate in a discontinuous manner, decelerating at microstructure barriers. The interaction with microstructure decreases as the crack grows, and its behavior as a long crack becomes treatable using Elastic-Plastic (EPFM) and Linear Elastic (LEFM) fracture mechanics continuum models.

\section{Analysis of Cyclic Strength Calculation}

The material strength to cyclic crack propagation is one of the most critical factors defining the suitability of the latter under the effect of cyclic loads. Kinetic fatigue diagrams in logarithmic axes: i.e., stress intensity factor (maximum $K_{\max }$ or its variation interval $\Delta K$ ) and the crack growth $\mathrm{v}$, have been developed based on experimental test results. Typical fatigue crack growth behavior in metals is shown in Fig 2.

They are intended to define the material strength to

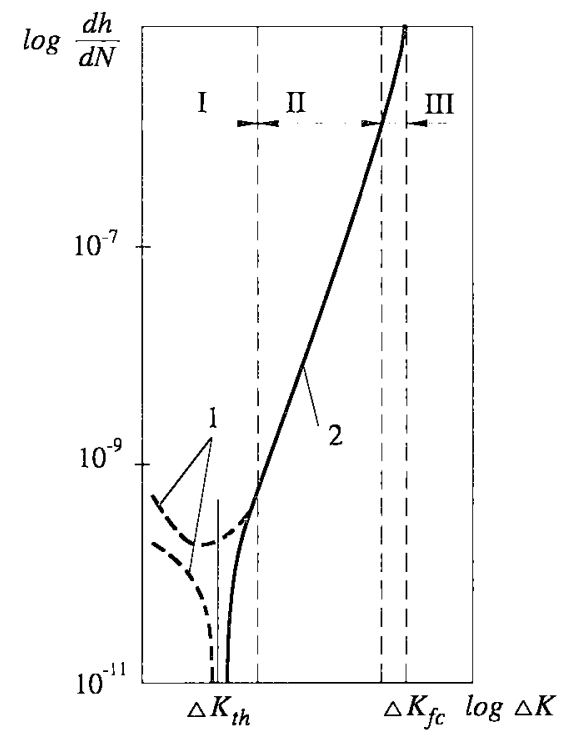

Fig 2. Typical fatigue crack growth behavior in metals: I, II, III - regions of the curve; 1 - small crack, 2 - sigmoidal curve 
crack propagation under cyclic loading conditions. The indicators of the crack propagation strength are the major parameters of the kinetic fatigue diagrams.

The formula below is a general expression of the kinetic fatigue diagram encompassing all three its constituents:

$\mathrm{v}=10^{-7}\left[F(\Delta K) / \Delta K^{*}\right]^{n}$,

where $F(\Delta K)=\left\{\begin{array}{l}\Delta K_{1}\left[\frac{\Delta K-\Delta K_{t h}^{*}}{\Delta K_{1}-\Delta K_{t h}^{*}}\right]^{\alpha}\left(\Delta K_{t h}^{*}<\Delta K<\Delta K_{1}\right), \\ \Delta K \quad\left(\Delta K_{1} \leq \Delta K \leq \Delta K_{2}\right), \\ \Delta K_{2}\left[\frac{(1-r) K_{f c}^{*} / \Delta K_{2}-1}{(1-r) K_{f c}^{*} / \Delta K_{2}-1}\right]^{\beta}\left(\Delta K_{2}<\Delta K<(1-r) \Delta K_{f c}^{*}\right),\end{array}\right.$

$\alpha=1-\Delta K_{t h}^{*} / \Delta K_{1}, \quad \beta=1-\Delta K_{2} /\left[(1-r) K_{f c}^{*}\right]$,

where $\Delta K_{I}$ and $\Delta K_{2}$ are the origin of the straight portion of the diagram; $K_{f c}^{*}$ stands for a conventional critical stress intensity factor; $\Delta K^{*}{ }_{t h}$ represents a physical threshold intensity factor.

The linear part (region II) of the kinetic fatigue curves, i.e. the second stage (according to the methodology adopted in fracture mechanics) can be described by means of a well-known P. Paris equation:

$$
\frac{d h}{d N}=C(\Delta K)^{n}
$$

From the engineering point of view it is not always necessary to have a kinetic fatigue diagram. The indicator $\mathrm{D} K_{t h}$ is very important for the structural defective elements.

The theoretical and experimental research of crack propagation shows that the limit stress intensity factor value is the increase, when material strength and yield decrease, when the dimension of little grain increases and it depends on the surrounding influence. Only the parameters, which can be established on the exploitation detail are of the size of a crack. The loading condition and the size of a crack are factors which decisived the longevity of a detail.

The design longevity of many presently operating devices has finished or is drawing to an end. Determining the remaining longevity is an important factor for assuring the safety of operating objects. The diagram of the longevity distribution of construction elements with defects is shown in Fig 3. Excluding non allowable op- erational states, the allowable size of the crack may be as follows:

$$
h_{a d m \max }>h_{a d m}>h_{d a d m},
$$

where $h_{\text {adm max }}$ is the operational marginal size of the crack which must never be exceeded because the component may break.; $h_{a d m}$ is the allowable control size of the crack determined by non-distrusting control methods; $h_{d a d m}$ is the marginal size of the non-propagating crack (the present crack does not propagate under operational loading).

Making use of the obtained dependencies of crack propagation it is possible the determine the duration of operation. The longevity of the construction elements from the initial value $h_{0}$ to the critical magnitude $h_{c}$ (it might reach the allowable regulating value) is determined by the number of cycles $N$. The relation between loading, the defect size and the change in the stress intensity ratio can be described by the following equation:

$$
\Delta K_{b}=\Delta \sigma_{R} \sqrt{\pi \cdot h} f(l),
$$

where $f(l)$ is the function depending on the shape of the crack and the geometry of specimen; $\Delta \sigma_{R}$ is endurance limit.

By means of the P. Paris equation we obtain the following:

$$
N=\int_{h_{0}}^{h_{c}} \frac{d h}{\left(\Delta \sigma_{R} \sqrt{\pi \cdot h}\right)^{n} f(l)} .
$$

After integrating the above equation, one can calculate after what number of cycles the crack will reach a critical size:

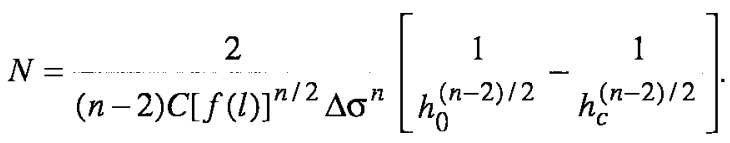

The minimum size of the crack to which the laws of

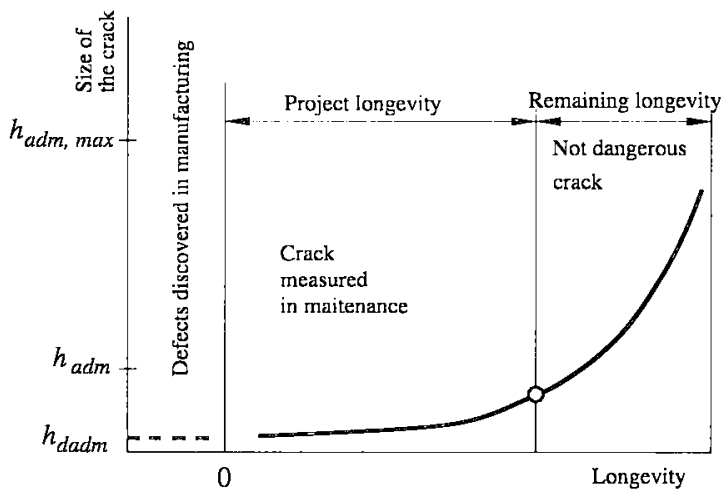

Fig 3. Diagram of longevity distribution 
linear fracture mechanics can be applied, may be calculated from the following equation:

$$
l_{0}=a\left(\begin{array}{c}
\Delta K_{t h} \\
\Delta \sigma_{R}
\end{array}\right)^{2}
$$

where a is a geometrical parameter.

\section{Experimental tests}

Experimental investigation was fulfilled in the Laboratory of Strength Mechanics at Vilnius Gediminas Technical University using a set of testing machines to produce static and cyclic loading effects. All the experiments were carried out using the experimental investigation systems developed by the authors themselves. The mechanical equipment to effect cyclic loading was laboratory-made. The experiment planning and processing theory was adapted to suit the unique testing procedure and the experimental investigation results.

The mechanical properties, structure, hardness of ADI materials are assessed by chemical composition and heat treatment. Chemical composition of austempered ductile iron ADI 6.2.02 and ADI 9.4.02 is presented in Table 2 and Table 3.

The cutup schemes of specimens from ADI 6.2.02 and ADI 9.4.02 are shown in Figure 4 and Figure 5. The original product had the form of a tooth gear.

Statical mechanical properties of ADI 6.2.02 and ADI 9.4.02 are presented in Table 4 and Table 5.

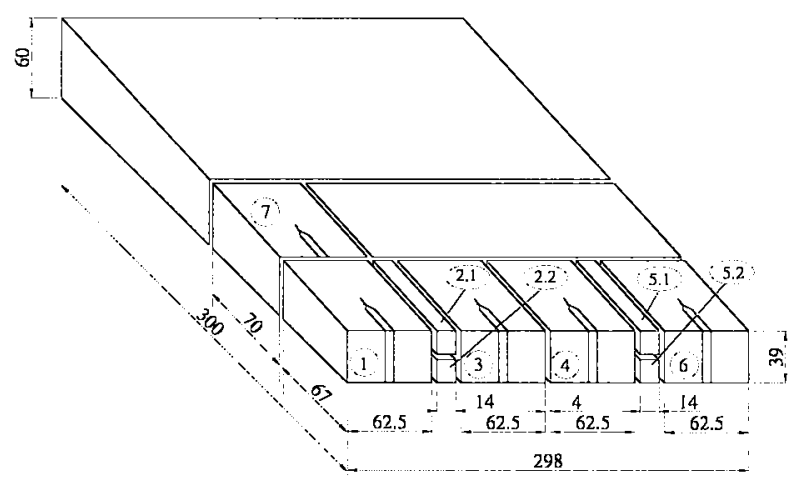

Fig 4. Scheme of the compact specimens places in the sample ADI 9.4.02

Table 2. Chemical analysis of ADI 6.2.02

\begin{tabular}{|c|c|c|c|c|c|c|c|c|c|c|c|c|c|c|c|}
\hline $\mathrm{C}$ & $\mathrm{Si}$ & $\mathrm{S}$ & $\mathrm{Mn}$ & $\mathrm{Cr}$ & $\mathrm{Sn}$ & $\mathrm{P}$ & $\mathrm{Mg}$ & $\mathrm{Ni}$ & $\mathrm{Cu}$ & $\mathrm{Ti}$ & $\mathrm{V}$ & $\mathrm{Mo}$ & $\mathrm{Al}$ & $\mathrm{Pb}$ & $\mathrm{Fe}$ \\
\hline$\%$ & $\%$ & $\%$ & $\%$ & $\%$ & $\%$ & $\%$ & $\%$ & $\%$ & $\%$ & $\%$ & $\%$ & $\%$ & $\%$ & $\%$ & $\%$ \\
\hline 3.61 & 2.22 & 0.008 & 0.351 & 0.032 & 0.008 & 0.015 & 0.064 & 1.968 & 0.805 & 0.011 & 0.013 & 0.395 & 0.008 & 0.005 & 90.482 \\
\hline
\end{tabular}

Table 3. Chemical analysis of ADI 9.4.02

\begin{tabular}{|c|c|c|c|c|c|c|c|c|c|c|c|c|c|c|c|}
\hline $\mathrm{C}$ & $\mathrm{Si}$ & $\mathrm{S}$ & $\mathrm{Mn}$ & $\mathrm{Cr}$ & $\mathrm{Sn}$ & $\mathrm{P}$ & $\mathrm{Mg}$ & $\mathrm{Ni}$ & $\mathrm{Cu}$ & $\mathrm{Ti}$ & $\mathrm{V}$ & $\mathrm{Mo}$ & $\mathrm{Al}$ & $\mathrm{Pb}$ & $\mathrm{Fe}$ \\
\hline$\%$ & $\%$ & $\%$ & $\%$ & $\%$ & $\%$ & $\%$ & $\%$ & $\%$ & $\%$ & $\%$ & $\%$ & $\%$ & $\%$ & $\%$ & $\%$ \\
\hline 3.50 & 2.24 & 0.011 & 0.353 & 0.031 & 0.009 & 0.016 & 0.064 & 0,2 & 0.799 & 0.011 & 0.014 & 0.407 & 0.008 & 0.005 & 92.242 \\
\hline
\end{tabular}

Table 4. Mechanical properties of ADI 6.2.02

\begin{tabular}{|c|c|c|c|c|c|c|c|c|}
\hline $\begin{array}{c}\text { Specimen } \\
\text { mark }\end{array}$ & $\begin{array}{c}\text { Initial } \\
\text { diameter }\end{array}$ & $\begin{array}{c}\text { Original } \\
\text { gauge } \\
\text { length } \\
\end{array}$ & $\begin{array}{l}\text { Proportion- } \\
\text { al stress }\end{array}$ & $\begin{array}{c}\text { Proof } \\
\text { strength }\end{array}$ & $\begin{array}{r}\text { Tensile } \\
\text { strength }\end{array}$ & $\begin{array}{c}\text { Modulus of } \\
\text { elasticity }\end{array}$ & $\begin{array}{c}\text { Percentage } \\
\text { reduction of } \\
\text { area }\end{array}$ & $\begin{array}{l}\text { Percentage } \\
\text { elongation } \\
\text { at fracture }\end{array}$ \\
\hline & $d_{n}$ & $L_{0}$ & $R_{\mathrm{sr}}$ & $R_{n_{7}}$ & $R$ & $E$ & $Z$ & $A_{31}$ \\
\hline & $\mathrm{mm}$ & $\mathrm{mm}$ & MPa & $\mathrm{MPa}$ & $\mathrm{MPa}$ & $\mathrm{GPa}$ & $\%$ & $\%$ \\
\hline ADI-121 & 7.99 & 30 & 535 & 699 & 934 & 145 & 3.5 & 4.7 \\
\hline ADI-122 & 7.99 & 30 & 528 & 705 & 918 & 144 & 4.0 & 4.3 \\
\hline ADI-151 & 7.99 & 30 & 539 & 701 & 926 & 145 & 4.2 & 4.3 \\
\hline ADI-152 & 7.99 & 30 & 538 & 703 & 952 & 145 & 4.7 & 5.7 \\
\hline
\end{tabular}

Table 5. Mechanical properties of ADI 9.4 .02

\begin{tabular}{|c|c|c|c|c|c|c|c|c|}
\hline $\begin{array}{c}\text { Specimen } \\
\text { mark }\end{array}$ & $\begin{array}{c}\text { Initial } \\
\text { diameter }\end{array}$ & $\begin{array}{c}\text { Original } \\
\text { gauge } \\
\text { length }\end{array}$ & $\begin{array}{c}\text { Proportion- } \\
\text { al stress }\end{array}$ & $\begin{array}{c}\text { Proof } \\
\text { strength }\end{array}$ & $\begin{array}{c}\text { Tensile } \\
\text { strength }\end{array}$ & $\begin{array}{c}\text { Modulus of } \\
\text { elasticity }\end{array}$ & $\begin{array}{c}\text { Percentage } \\
\text { reduction of } \\
\text { area }\end{array}$ & $\begin{array}{c}\text { Percentage } \\
\text { elongation } \\
\text { at fracture }\end{array}$ \\
\hline & $d_{0}$ & $L_{0}$ & $R_{n r}$ & $R_{o, 2}$ & $R_{m}$ & $E$ & $Z$ & $A_{a}$ \\
\hline & $\mathrm{mm}$ & $\mathrm{mm}$ & $\mathrm{MPa}$ & $\mathrm{MPa}$ & $\mathrm{MPa}$ & $\mathrm{GPa}$ & $\%$ & $\%$ \\
\hline ADI-21 & 7.99 & 30 & 597 & 834 & 1077 & 145 & 9.8 & 11.2 \\
\hline ADI-22 & 7.99 & 30 & 617 & 881 & 1069 & 142 & 11.4 & 11.8 \\
\hline ADI-51 & 7.98 & 30 & 593 & 841 & 1034 & 144 & 8.1 & 8.9 \\
\hline ADI-52 & 7.99 & 30 & 594 & 845 & 1046 & 145 & 9.3 & 10.7 \\
\hline
\end{tabular}




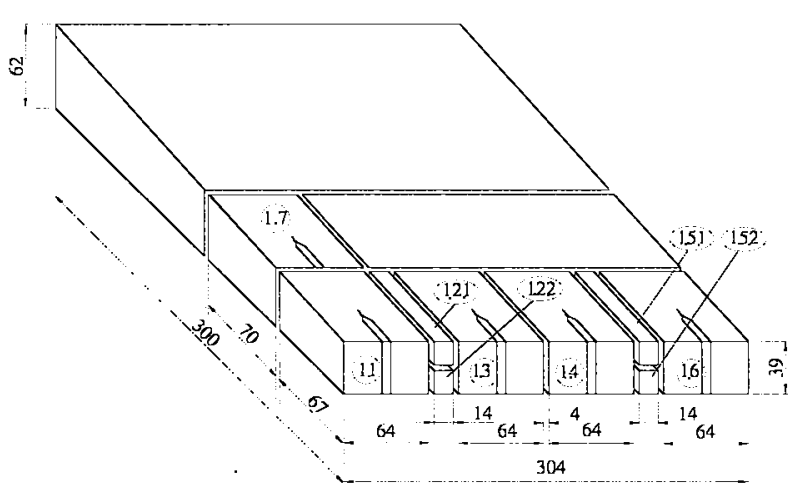

Fig 5. Scheme of the compact specimens places in the sample ADI 6.2 .02

The tensile specimens and the compact specimens were used for structure investigation. The structure consists of bainite and spherical graphite.

The Brinell hardness of compact tension specimens was measured and the difference in hardness was observed: $\mathrm{BHN}=300-311$ for $\mathrm{ADI} 6.2 .02$ and $\mathrm{BHN}=$ 313 - 323 for ADI 9.4.02.

Compact specimen CT (Fig 6) has been produced in order to determine a threshold stress intensity factor $\mathrm{D} K_{t h}$. The work procedure is as follows: the crack in the notch of the specimen under cyclic loading grows to reach $0.5-1 \mathrm{~mm}$. Then the external load was reduced down by at least $10 \%$; thereafter, the crack is again cyclically grown to reach the aforementioned level and again, the external load is lowered down. Such regular actions in terms of crack growth and load reduction help to reach the limit when, within $10^{7}$ cycles, crack growth is no longer observed by measurement means. The experimental tests have been conducted in compliance with the requirements (as regards loading conditions, the size of the crack and its measurement mode) established for the work procedure.

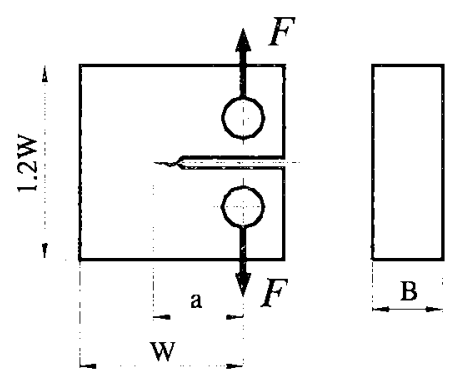

Fig 6. Compact tension specimen $(\mathrm{B}=25 \mathrm{~mm})$

The calculation of $\Delta K$ was made to the parameters used in the fracturing process that was derived, when testing the compact tension specimens, formulas for calculations according to ASTME 647-93 and recommendations [4].
Stress intensity factor is:

$$
\begin{aligned}
& K=\left(F / B W^{1 / 2}\right) \cdot f(\lambda), \quad \lambda=a / W \\
& f(\lambda)=\left[(2+\lambda) /(1-\lambda)^{3 / 2}\right] \cdot(0.866+4.64 \lambda \\
& \left.-13.32 \lambda^{2}+14.72 \lambda^{3}-5.6 \lambda^{4}\right) .
\end{aligned}
$$

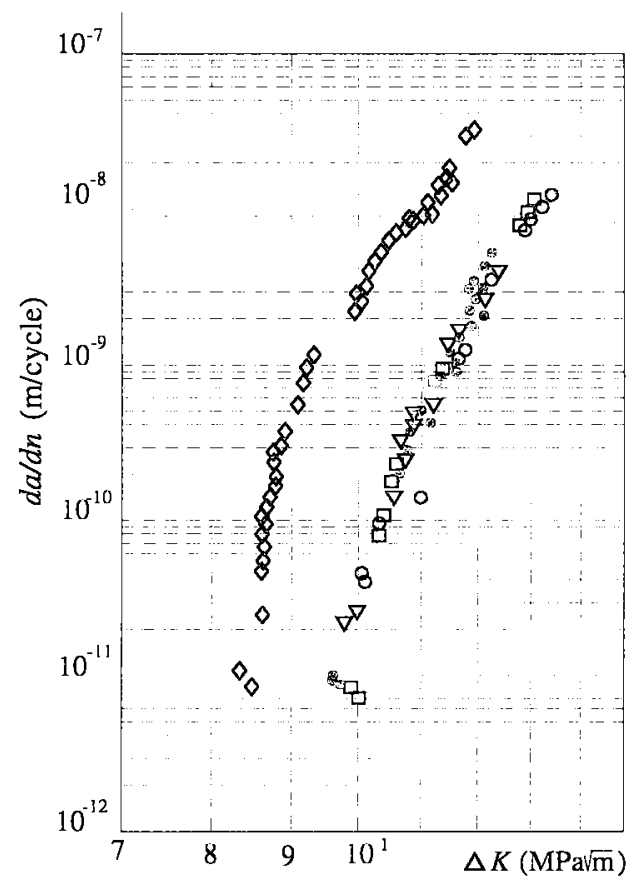

Fig 7. The growth of fatigue crack in specimens from ADI 9.4.02 materials: $-1,-3, \nabla-4,0-6,0-7$

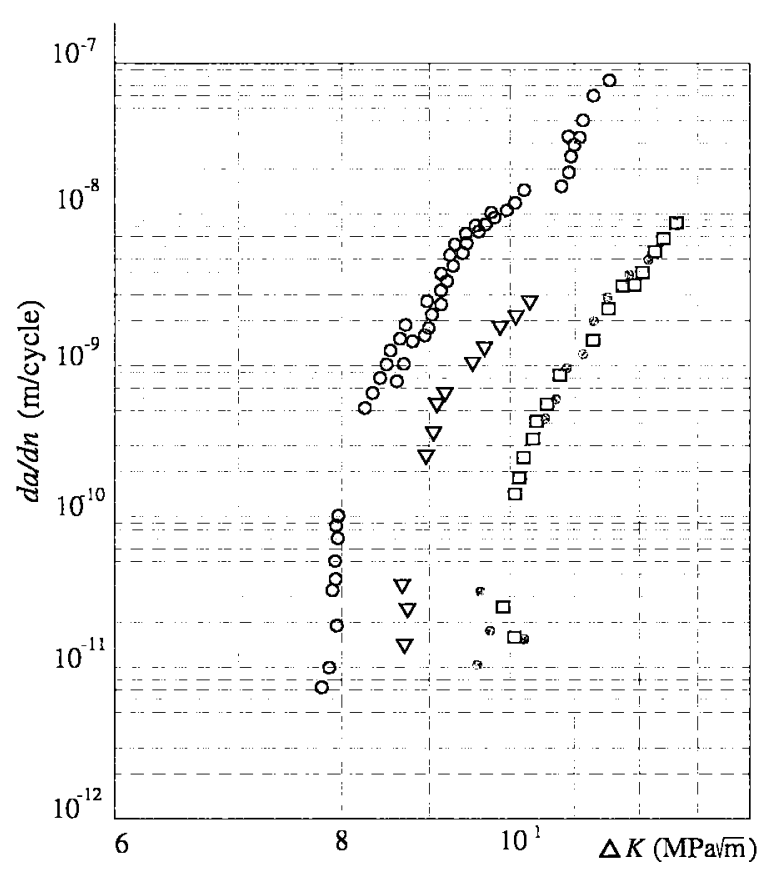

Fig 8. The growth of fatigue crack in specimens from ADI 6.2.02 materials: $-13, \Delta-14,-16,0-17$ 
Stress intensity factor range is: $\Delta K=K_{\max }-K_{\min }$ and stress ratio $R=F_{\text {min }} / F_{\text {max }}=K_{\min } / K_{\max }$, where $K_{m i}$ and $K_{\max }$ is the minimum and the maximum stress intensity factor in the cycle of loading.

Fig 7 and Fig 8 represent the relationship between stress intensity factor range $\Delta K$ and crack growth ratio.

\section{Conclusions}

1. The results of mechanical properties investigation show, that the austempered ductile iron ADI 6.2.02 with larger quantity of nickel is less plastic than the austempered ductile iron ADI 9.4.02. The Brinell hardness of $A D I$ 6.2.02 is $B H N=300-311$ and ADI 9.4 .02 is $\mathrm{BHN}=313-323$.

2. The investigations of structure show, that structure is stable and fractionally changed on the crest of compact tension specimen notch.

3. According to the investigations the stress intensity factor (threshold) is $\Delta K_{\text {th }}=9,8 \mathrm{MPa} \mathrm{V}_{\mathrm{m}}$ for the $\mathrm{ADI}$ 6.2.02 and $\Delta K_{t h}=8,6 \mathrm{MPa} \sqrt{m}$ for the ADI 9.4.02.

4. The stress intensity factor $\Delta K_{t h}$ of the specimens CT which are cut in the apex of a gear tooth is larger than the intensity factor of the CT which are cut $80 \mathrm{~mm}$ from the apex of a gear tooth.

5. The analysis of crack formation and the view of breaks show that a crack springs up in nearly all of the notches edges of compact specimens and spreads cornerwise.

6. Carried out investigations are insufficient for the complete evaluation of austempered ductile iron ADI 6.2.02 and austempered ductile iron ADI 9.4.02 suitability for the production of transport equipment elements.

\section{References}

1. Marrow, T. J.; Cetinel, H.; Venslovas, A.; Leonavicius, M. $\mathrm{X}$-ray Tomography of Short Fatigue Cracks in Ductile Iron. In: Proceedings of the $14^{\text {th }}$ Biennel Conference on fracture. European Conference Fracture, 14, 2002, p. 443-450.
2. Marrow, T. J.; Cetinel, H.; MacDonald, S.; Withers, P. J.; Venslovas, A.; Al Zalmach, M.; Leonavicius, M. Short fatigue cracks in ductile cast iron. Mechanics (Mechanika), No 3, 2001, p. 5-10.

3. Dorazil, E. High strength austempered ductile cast iron. Ellis Horwood New York, 1999. 250 p.

4. Anderson, T. L. Fracture mechanics. Fundamentals and applications. CRC Press, Boston, 1991. 793 p.

5. McDowell, D. L. Basic issue in the mechanics of high cycle metal fatigue. International Journal of Fracture, 80, 1996, p. 103-145.

6. Hertzberg, R. W. Deformations and fracture mechanics of engineering materials. John Willey\&Sons, Inc. New YorkSingapoore, 1996. $768 \mathrm{p}$.

7 Carihaloo, B. L. Fracture mechanics and structural concrete. Longman Scientific and Technical. England, 1995. $330 \mathrm{p}$.

8. Trashchenko, V. T.; Lyalikov, S. M. The influence of surface defects on high cycle fatigue of engineering material. Strength problems (Проблемы прочности).1, 1996, р. 516 (in Russian).

9. El Haddat, H.; Smith, K. N.; Topper, T. H. Fatigue crack propagation of short crack. Journal of Engineering Materials and Technology, Vol 101, No 1, 1979, p. $42-46$.

10. Greno, G. L.; Otegui, J. L.; Boeri, R. E. Mechanisms of fatigue crack growth in austempered ductile iron. International Journal of Fatigue, 21, 1999, p. 35-43.

11. Leonavičius, M.; Fliotovienè, R.; Stupak, E. The stressstrain analysis in plates with operational and industrial defects. Archives of Civil Engineering, XLV, No 3, 1999, p. 443-452.

12. Proceedings of world conference. Austempered Ductile Iron. Ed. Boshen, R.; Bomas, H.; Mayr, P. Ed. American Foundrymen's Society, Des Plaines. IL, USA 1991. 468 p.

13. ASTM E 647-93. Standard Test Method for Measurement of Fatigue Crack Growth Rates.

14. ASTM E 1681-93. Standard Test Method for Determining a Threshold Stress Intensity Factor for Environment Assisted Cracking of Metallic Materials Under Constant Load.

15. Jurevičius, J.; Sivilevičius, H.; Spruogis, B. Analysis of wearing-out causes for revolving-blade mixers and their reliability impprovement. Transport, Vol XVIII, No 1, Vilnius: Technika, 2003, p. 40-48. 